\title{
"Summer syndrome" in Litopenaeus stylirostris grow out ponds in New Caledonia: Zootechnical and environmental factors
}

\author{
Hugues Lemonnier1,2*, Alain Herbland1, Lucas Salery1, Benoît Soulard1
}

\author{
1- Laboratoire d'Aquaculture Calédonien, IFREMER, BP2059, 98846 Nouméa Cedex, New \\ Caledonia \\ 2- Centre de Recherche sur les Ecosystèmes Littoraux Anthropisés, Place du séminaire, BP7, \\ 17139 L'Houmeau, France
}

Corresponding author : hugues.lemonnier@ifremer.fr

\begin{abstract}
The "Summer Syndrome", a septicemic vibriosis caused by Vibrio nigripulchritudo, is responsible for one of the two main seasonal mortalities which affect shrimp aquaculture in New Caledonia. It was identified for the first time in December 1997 in an intensive shrimp farm (called farm DF) and has been enzootic ever since. The "Summer syndrome" affects shrimp during warm-season growout. Although the geographic area concerned is limited, it is a potential threat for the industry in that the disease could spread. Analysis of grow out data from 1991 to 2002 in this farm was carried out in order to characterize the disease and the environmental conditions in relation to mortality. Results of farm DF were compared to data from farms not affected by the disease (called farms HC). The "Summer syndrome" occurs during the warm season which is characterized by an increase in water temperature and sunny duration. This disease is characterized by simultaneously highest densities and weakest drying duration between crops in the farms studied. Between 1991 and 2002, the increase of feed input and nitrogen rate in feed has led to a significant increase of the growth rate over the years in farm DF. At the same time, water management has not changed and has induced an increase in environmental waste production. In consequence, an early eutrophication of water is observed, which is concomitant with the beginning of the mortality outbreaks. This could play a role by inducing directly or indirectly a stress for shrimp and/or a growth and/or virulence factors of the pathogen.
\end{abstract}

Keywords: Shrimp culture ponds; Vibriosis; Pond management; Eutrophication 


\section{Introduction}

Shrimp aquaculture in New Caledonia is confined to the species Litopenaeus stylirostris and is a developing industry. The two growout techniques used are semi-intensive $\left(20 \mathrm{shrimp} / \mathrm{m}^{2}\right.$; 7-11 ha ponds; without aeration) and intensive (30 to 40 shrimp $/ \mathrm{m}^{2} ; 3-4$ ha ponds; with aeration) (Herlin, 1999). However, it is subject to seasonal mortalities during growout. Since 1993, penaeid shrimp reared in New-Caledonia during the cold period are affected by one other seasonal mortality named "syndrome 93". Mortality occurs as simultaneous epizootics on distant shrimp farms, following a sudden drop in temperature during the transition seasons (Mermoud et al., 1998). Since then, this disease has inflicted serious losses on all the farms and thus must be considered as an economically significant disease. Vibrio penaecida is the etiological agent of this disease (Costa et al., 1998; Goarant et al., 1999). As a consequence, the whole industry has become seasonal and produces essentially during the warm season (Harache and Herbland, 2004). In December 1997, a case of mortality from two ponds in an intensive farm (farm DF) was investigated due its uncommon feature: it occurred in summer conditions and thus did not fit the typical "syndrome 93" profile. A septicemic vibriosis due to Vibrio nigripulchritudo was identified and this new disease named "Summer syndrome" turned out to be almost enzootic in farm DF and has affected all its crops ever since (Goarant et al., 2004; 2006). Farm DF has a similar pond size (between 3.3 and 3.7 ha), for a total surface of 34 ha. Development of this disease corresponded to the climatic phenomenon named La Niña (1998 - 2000) (NOAA, 2005) characterized by strong precipitations (Nicet and Delcroix, 2000) and high temperatures (National Weather Service, Com. Pers.). From 1994 to 1996 and in the absence of mortality outbreaks on farm DF, the average survival rate was $58.4 \pm 2.5 \%$. Since farm DF has been affected by the "Summer syndrome", final survival levels after harvest vary between 22 and 38\%, depending on the year (Unpublished data). Since 2000, V. nigripulchritudo strains have been found in several shrimp farms, although the "Summer syndrome" is still limited to one particular area, affecting, since 2003, a second adjoining farm (Goarant et al., 2006). As a consequence, the Summer syndrome is considered as a potential threat for the industry in that the disease could spread (Harache and Herbland, 2004; Goarant et al., in press).

The study of the virulence characteristics of some isolated strains of $V$. nigripulchritudo by Goarant et al. (2006) showed that pathogenic and non-pathogenic strains occur in farm environments and that both may be found at the same time in one pond. Moreover, the results suggest a persistence of pathogenic strains in wet zones of the pond sediment at low concentrations between crops in the affected farm DF, and their development during the rearing cycle as a cause of shrimp infection (Goarant et al., 2006). The Vibrio may be detected as early as 11 days after stocking in the pond sediment, 40 and 44 days in sampled shrimp and pond water respectively (Goarant et al., 2006).

Shrimp susceptibility, if it is affected, determines the development of the disease. The first dead shrimp due to the Summer syndrome are observed after an average of 58 days of rearing, for an average weight of $5.4 \mathrm{~g}$, and during a phase of high growth. The growth rate is not affected by the disease. Shrimp in late premolt stage D2 and early postmolt stage A appeared to be the most affected at some points of the mortalities (Mugnier et al., 2004). Successive mortality peaks can be observed within a pond. Mortalities start at different dates, depending on the stocking date, but some synchronicity in mortality peaks between ponds could be observed. The intensity of mortality is variable depending on the pond. This synchronicity suggests a common triggering factor. The variation in the intensity of mortality outbreaks suggests the implication of one or more factors associated with the intensity of the syndrome. The outbreak and impact of the disease can be influenced by many factors, a concept neatly expressed in the "epidemiological triad" of Snieszko (1974) and discussed more recently by 
Lightner and Redman (1998). The disease is an end result of a complex interaction between the shrimp, its environment and the pathogen itself. However, very few studies have investigated factors for bacterial disease in aquatic culture systems.

Environmental factors include all biotic or abiotic components of the farms and can be classified into physical, biological and farm management factors. The identification of these factors contributes greatly to a more targeted health management strategy including all decisions made that influence the expression of the disease (stocking density, water quality management, feeding management, pond bottom management) (Fegan and Clifford, 2001; Lotz et al., 2001). The aim of the present study was to identify the major zootechnical and environmental factors which trigger the Summer syndrome by studying data from farms affected (farm DF) or not (farms HC) by the disease.

\section{Material and methods}

\subsection{Growout ponds}

Shrimp aquaculture in HC farms is carried out in large earthen ponds (3 to 10 ha) built on salt marshes (Herlin, 1999). Ponds are filled with filtered water $(700 \mu m)$ using pumps and are drained by gravity. Post-larvae are stocked between 20 and 40 per $\mathrm{m}^{2}$. In summer, growout lasts 5 months, after which shrimp reach a mean weight in the range 18 - 40 grams. The mean yield ranges from 2 to 5.5 tonnes per hectare and per year, depending upon management strategies (semi-intensive without aeration or intensive with aeration). Farm DF has a similar pond size between 3.3 and 3.7 ha, for a total surface of 34 ha. Ponds are equipped with aerators.

\subsection{Data farm records}

A first data base gathering all of the synthetic data (stocking density, stocking date, crop duration, sun drying duration, food conversion ratio, survival, feed distributed, etc...) of crops carried out in New Caledonia between 1991 and 2002 was used. It includes 707 crops derived from eight farms. A second data base gathering 39 rearings stocked in the inter season (August -November) between 1991 and 2002 in farm DF and 74 rearings from farms HC were analyzed. The "Summer syndrome" was observed in 26 rearings on farm DF. Records of weekly growth data, daily distributed feed, the daily number of dead shrimp, final survivals, daily water exchange, daily oxygen and temperature (6:00 AM and 4:00 PM) and salinity (about twice a week) were taken from the farms' record books. Daily pond mortality was evaluated by counting dead and moribund shrimp on the pond edges and on feeding control trays. Feed conversion ratio is the total amount of feed distributed in a pond relative to the wet weight gain of shrimp biomass. Nitrogen and water content in the feed was provided by the manufacturer.

\subsection{Water quality survey}

Chlorophyll-a analysis was carried out over the first 120 days of rearing in two ponds in 1994 and three ponds in 2001 by a scientific team. The second data base described above includes these five rearings. Water samples were collected in the morning twice a week. To estimate Chlorophyll-a (chl-a) concentration, water samples of $25 \mathrm{ml}$ were filtered through GF/F Whatman filters and analysed by the fluorometric method before and after acidification (Holm-Hansen et al., 1965).

\subsection{Data and statistical analysis}

A non linear power regression $\left(y=a x^{\wedge} \mathrm{b}\right)$ was applied to weight data from day 0 to day 120 after stocking (Statview computer software). The growth rate was calculated from the 
regression ( $\mathrm{P} \geq 0.99$ ). Shrimp weight and growth rate were calculated at $\mathrm{d} 50$ ( $\mathrm{d}$ as day), just before the first mortality was observed in farm DF, in order to see if they could be potential triggering factors of the disease.

The comparisons of (i) the weight, the growth, and the days at which first dead shrimp were observed between stocking months and (ii) the final density and survival between years were carried out with ANOVA. Survival rates were arcsin transformed prior to statistical analysis. Regression analysis were used to correlate (i) the number of dead shrimp observed on pond edge between d50 and d120 and time (ii) survival at the end on the rearing and stocking density, (iii) final survival with the number of day when mortality was observed on the pond edges or on feeding trays and (iv) between stocking density and final density.

Considering the strategy of Boyd and Tucker (1995), a gross mass balance for the fate of nitrogen in feed added to shrimp ponds after 50 days of rearing was developed based on estimates of survival, the amount of feed added, the nitrogen content of feed and shrimp. The concentrations were $70.1 \pm 1.1$ and $32.2 \pm 4.6 \mathrm{mg} \cdot \mathrm{g}^{-1}$ wet weight respectively (Martin et al., 1998; Lemonnier et al., 2003).

Descriptive statistics are presented as a mean, standard deviation of the mean, minimum (min), maximum (max) and frequency. Regression analysis was carried out to determine the relationship between zootechnical results.

\section{Results}

\subsection{Mortality characteristics}

Abnormal mortalities appeared in December 1997 in two ponds at d68 and d72 of rearing and since 1998 have been observed in all the ponds stocked in the warm season. The disease started to appear in November for stockings made in August, and in December for stockings made in September and October. Mortality for crops stocked in September to November appeared $56 \pm 6$ days after stocking $(\mathrm{N}=23)$. If the ponds were stocked in August, mortality appeared significantly later $(\mathrm{p}<0.01), 72 \pm 3$ days after stocking $(\mathrm{N}=3)$, but at the same weight $(4.3 \pm 0.6 \mathrm{~g})(\mathrm{p}>0.05)$ and growth rate $(0.17 \pm 0.01 \mathrm{~g} /$ day $)(\mathrm{p}>0.05)$.

The intensity of mortality was variable, depending on the pond and the year. Mortality can be weak but chronic, or it can be expressed more strongly and most noticeably. In this case, mortality outbreaks follow a Gaussian curve and are successive within a pond (unpublished data). Table 1 summarizes the characteristics of mortalities from 1997 to 2001. The number of dead shrimp observed on pond edges increased between 1997 and 2001 as an exponential curve $\left(y=11.6 \operatorname{Exp}^{(0.46 x)} ; \mathrm{x}\right.$ is the age of the farm). Some very high mortality levels occurred in some crops with more than 500 dead shrimp noticed on pond edges. This was observed four times between 1998 and 2001 when oxygen values were low in the morning $(<1.5 \mathrm{mg} / \mathrm{L})$ or in the evening $(<5 \mathrm{mg} / \mathrm{L})$.

The final survival decreased significantly with the cumulated number of days when mortality was observed (negative linear regression, $\mathrm{r}^{2}=0.47, \mathrm{p}<0.01$ ). Mean final density and mean survival (Tab. 1) ranged from 6.9 and 10.7 shrimp $/ \mathrm{m}^{2}$ and from $22.3 \%$ and $36.7 \%$ respectively. 1999 and 2000 showed the lowest final density and survival $(\mathrm{p}<0.05)$. There is a significant relationship $(\mathrm{p}<0.05)$ between stocking density (SD) and survival (S) at the end of the rearing $(S=57.9-0.95 \times \mathrm{SD}$ ). This correlation explains only $24.3 \%$ of the variability observed for survival. Ponds stocked with the highest density (39 shrimp/ $\mathrm{m}^{2}$ ) show the lowest final survival $(<20 \%)$. However, there is no significant correlation between stocking density and final density $(\mathrm{P}>0.05)$. 


\subsection{Farm management practices}

A change in management practices was observed between 1991 and 2001. The average length of sun-drying increased significantly over these years, from $37 \pm 10$ days to $156 \pm 34$ days (positive linear regression, $\mathrm{r}^{2}=0.68, \mathrm{p}<0.01$ ). However, sun drying was extremely short between some crops and lower than 10 days during the first six years. From 1998 up to now, all the ponds were dried between May and August. The highest stocking density was observed in 1997, which was the first year with mortality related to Vibrio nigripulchritudo (Goarant et al., 2004) (Fig. 1). Thereafter, stocking density tended to decrease. Figure 1 compares farm DF management with HC farms management by taking into account the stocking density and the length of sun drying. Before and at the onset of the disease, farm DF is characterized by the highest stocking density associated with the shortest drying duration.

\subsection{Pond management practices}

Between 1991 and 2002 and for ponds stocked in September to November, growth calculated at d50 increased significantly over the years in all farms, including farm DF (Fig 2). In farm DF, this corresponds to an increase in mean weight after 50 and 120 days of rearing from 2.6 to $4.6 \mathrm{~g}$ and 12.6 to $22.9 \mathrm{~g}$ respectively. In parallel, the cumulated food distributed on the first 50 days after stocking in farm DF increased from 34 to $157 \mathrm{~g} / \mathrm{m}^{2}$ respectively (Fig 3a). The percentage of nitrogen in the feed increased also significantly with year from 5.8 to $6.5 \%$ (positive linear regression, $\mathrm{r}^{2}=0.75, \mathrm{p}<0.01$ ). Water management did not change between 1991 and 2002 (Fig. 3b). Fig 3c shows an increase in nitrogen waste produced in relation with the year from 0.8 to $7.9 \mathrm{~g} / \mathrm{m}^{2}$.

\subsection{Pond environment and development of the disease}

Table 2 (mean $+\mathrm{SD}$, mini, maxi) shows the water characteristics observed the day when the first dead shrimp were observed. The temperature ranged from 24 to $29.9^{\circ} \mathrm{C}$ in the morning and from 24 to $32.5^{\circ} \mathrm{C}$ in the evening. The first dead shrimp were observed both during the increase or decrease period of the temperature. Oxygen AM ranged from 1.1 to $4.7 \mathrm{mg} / \mathrm{L}$. Salinity varied between 36 and $41 \%$ according to the years and from the ponds.

The distribution of abiotic factors in relation to mortalities observed between d50 and d120 ( $\mathrm{N}=944)$ were calculated. The observations are centred a temperature, salinity, morning and evening oxygen at $29^{\circ} \mathrm{C}, 37 \%$ o, $4 \mathrm{mg} / \mathrm{L}$ and $10 \mathrm{mg} / \mathrm{L}$ respectively. Oxygen AM minima and maxima were 1 and $7 \mathrm{mg} / \mathrm{L}$. The values for oxygen PM were 3.3 and $20 \mathrm{mg} / \mathrm{L}$. Salinity ranged from 35 to $41 \%$ and mean temperature from 22.7 and $32.9^{\circ} \mathrm{C}$.

Oxygen AM and net oxygen budget distribution (\%) measured between d60 and d120 for ponds stocked between September and November are shown on Figure 4. More than 60 crops reared in farms DF or HC between 1991 and 2001 are represented on these graphs. Crops affected by the Summer Syndrome are not specifically related to the low dissolved oxygen values observed on the left of figure 4A. The weakest distributions were found for semiintensive rearing without aeration, which is not the case of farm DF. However, the crops with mortality show large variations in oxygen concentrations between morning and evening (figure 4B).

We found a significant increase in the frequency of the net oxygen budget, which was higher than $8 \mathrm{mg} / \mathrm{L}$ in farm DF farm over the years. This increased from 1\% to 49\% between 1996 and $2001\left(\mathrm{Y}(\%)=0.52 \mathrm{e}^{0.77 \mathrm{x}} ; \mathrm{x}=\right.$ number of years from 1996; $\left.\mathrm{r}^{2}=0.97 ; \mathrm{N}=6\right)$.

A survey conducted in farm DF in 2001 showed an increase of chlorophyll-a concentrations in the water column in parallel with the mortality outbreaks observed in three ponds after 69, 73 and 76 days of rearing respectively (Fig. 5). This figure also shows that the increase of the chlorophyll-a concentration in the water column occurred earlier in 2001 than in 1994.

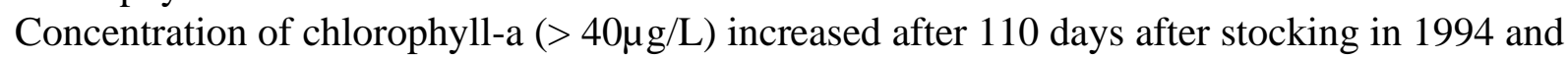


after only 75 days in 2001. Net oxygen budget was significantly correlated with chlorophyll-a concentration in the water column $\left(\mathrm{Y}=1.215 \mathrm{e}^{0.393 \mathrm{x}} ; \mathrm{x}=\right.$ chlorophyll-a concentration ; $\mathrm{Y}=$ net oxygen budget $\left.(\mathrm{mg} / \mathrm{L}) ; \mathrm{r}^{2}=0.65 ; \mathrm{N}=131\right)$.

\section{Discussion}

Before and during the Summer syndrome and compared to the other farms, farm DF cumulated the shortest drying time and the highest stocking densities. Duration of sun drying and stocking densities are listed as major causes of the appearance and/or amplification of the pathology (Bell and Lightner, 1987, Lightner, 1993). For example, disease occurrence in shrimp ponds in Hainan in China was closely associated with excessive stocking density (Spaargaren, 1998). The objective of a drying period is to aerate soil and encourage oxidation of reduced inorganic compounds and organic matter. Pond drying can greatly retard the rate of organic matter accumulation in pond bottom soil (Boyd, 1995). The short drying time on farm DF could have lead to an accumulation of organic matter which was favourable to the development of Vibrio and pathogens. In fact, Vibrio are more frequent where soft benthos occurs in combination with high organic loads, (Balebona et al., 1998). Vibrio can be considered as good indicators of organic enrichment in sediment (La Rosa et al., 2001). In August 2000, sediment was removed from all pond bottom and water supply canals and the drying duration increased between 1998 and 2001. However, no positive consequences on the disease following these practices were found. It was shown that thorough drying of the soil eliminates Vibrio, populations that get established within the ponds always enter with the incoming water (Lavilla-pitogo et al., 1998). Goarant et al. (2006) suggest that, between crops, there could be a persistence of pathogenic strains at low concentrations in wet zones of the pond sediment in farm DF, with a possible development during the rearing cycle as a cause of shrimp infection. Proper pond preparation has been found to be the most successful way to prevent disease problems in subsequent production cycles (Nash, 1990) but does not seem to have a curative effect.

The severity of the "Summer syndrome" is correlated with stocking density. However, the correlation between stocking density and final survival explains only $24.3 \%$ of the survival variability. We have also noted that final density remains the same regardless of stocking density and ranges between 6.9 to $10.7 \mathrm{shrimp} / \mathrm{m}^{2}$. Caldéron et al. (2000) reported that a lower incidence of WSSV-positive samples was reported in ponds stocked at less than 7.5 shrimp $/ \mathrm{m}^{2}$. We can conclude that density has a weak but significant effect on the severity of the disease. However, we believe that very high stocking densities increase the risk of transmission of the disease within the pond. Indeed, by increasing density, cannibalism can contribute to the rate of transmission of the disease (Fegan and Clifford, 2001). Moreover, high pond densities will facilitate the spread of pathogens between ponds (Kautsky et al., 2000).

Mortality increased between 1998 and 2001 without having an obvious impact on final survivals. The mortality was higher and faster. In parallel, the growth rate increased and as a probable consequence, there was an increase in molting frequency. High molting frequency could increase the exposure frequency to the pathogen and/or decrease the shrimp's ability to combat stress. Le Moullac et al. (1997) observed significant changes of total hemocyte count (THC) and phenol oxydase (PO) activity in premolt and intermolt shrimp. In an experimental infection, the authors confirmed that at the premolt stage, the shrimp are more sensitive to infection, exhibiting $48 \%$ mortality during premolt, and only $21 \%$ mortality during intermolt. This increase of growth rate over the years also occurred on the other farms, without the development of the disease. However, an increasing growth rate could play a part in the 
expression of the disease. This hypothesis has to be tested and the consequence on the molting frequency has to be studied.

Between 1991 and 2002, the change in growth rate on farm DF could be explained by the increase (i) of feed input and (ii) of the percentage of nitrogen in the feed. At the same time, water management did not change and induced an increase in environmental waste production (Lemonnier and Faninoz, 2006). As a consequence of the increasing environmental waste production, an earlier eutrophication of water was observed, which was concomitant with the outbreaks of mortality. The significant regression of net oxygen budget versus chl-a indicates that these two parameters are closely related. We found a significant increase in the frequency of the net oxygen budget on farm DF in relation to time. This result suggests an increase of the eutrophication level with time. In a survey conducted in 2002-2003, Vibrio nigripulchritudo was found for the first time in the water column on day 44. It was detected more frequently and at higher concentrations during the outbreak (Goarant et al., 2006) and the eutrophication of the pond ecosystem (Lemonnier and Personnel du LAC, 2004). This early eutrophication was not observed on farms HC and could have an effect on the growth and virulence of Vibrio nigripulchritudo. Horowitz and Horowitz (2001) reported that pathogenic and opportunistic bacteria thrive in eutrophic environments more than in oligotrophic environments that are poor in nutrients and organic matter. In New Caledonia, the Syndrome 93 mortality was correlated to the abundance of both picoplancton and Vibrio and to the pheopigment concentration and to a lesser extent to chlorophyll-a and particulate matter concentrations (Lefevre et al., 2004). However, the eutrophication level was not the sole explanation for the disease. Level observed in this study (>60 $\mu \mathrm{g} / \mathrm{L})$ was measured sometimes in other pond environment without disease outbreak but later during the rearing (Martin et al., 1998; Lemonnier and personnel du LAC, 2004; Lemonnier and Faninoz, 2006). Low oxygen levels were sometimes recorded in parallel with very strong mortalities and appear to exacerbate losses due to the Summer Syndrome. A low level of oxygen increases the sensibility to vibriosis in penaeid shrimp (LeMoullac et al., 1998). However, as a general rule, oxygen, salinity and temperature remain in a range considered as not stressful for shrimp. There was no difference in oxygen level in the morning between farms HC and DF farm. DF farm is characterized by a stronger variability of its pond environment in comparison to the other farms in the industry.

Excessive daily fluctuations in oxygen concentration were recorded at the beginning and during the Summer syndrome mortalities. Daily variability of dissolved oxygen appears to exacerbate losses due to the white spot syndrome virus (Fegan and Clifford, 2001). Excessive fluctuations in abiotic factors like oxygen, salinity and temperature can increase the susceptibility of shrimp to disease (Kautsky et al., 2000). Fluctuations in normal environmental conditions have a significant effect on the virulence of Vibrio harveyi, with salinity being more lethal to shrimp than temperature (Shivappa, 1997).

\section{Conclusion}

Factors like high growth rate, although it was recorded without causing major losses in other farms, could be considered as a weakening factor for shrimp. Temperatures higher than 23$24^{\circ} \mathrm{C}$ seem to be necessary for the disease to develop with a range of 26 and $32^{\circ} \mathrm{C}$ is the most appropriate. An early eutrophication of water could play a role by inducing directly or indirectly a stress for shrimp and/or a growth and/or virulence factors of Vibrio nigripulchritudo. However, factors may act synergistically to explain the Summer Syndrome. These hypotheses have to be tested. During the summer of 2002-2003, a field survey on the changes on (1) the pond ecosystem, (2) the biological characteristics, the physiological and immunological status of the shrimp and (3) the pathogen was conducted on two farms, one 
affected by the disease and the other not. For the study of the pond ecosystem, a sampling strategy of the chemical and biological parameters (water column and sediment) was carried out in order to validate the observations resulting from the farm data. The results of the pond ecosystem analysis and shrimp physiology/immunology are currently being analyzed and will hopefully bring new insights to this disease.

\section{Aknowledgement}

This work was supported by research grants from the Northern and Southern Provinces of New Caledonia. The authors would like to thank the owners of the private farms and their employees for allowing us access the data and permitting to publish these results. We also want to thank D. Coatanea, J. Herlin, A.L. Marteau, C. Mugnier, J. Patrois, Y. Thomas, B. Wapotro of the Département Aquacole Calédonien who kindly helped us for this work.

\section{References}

Balebona, M.C., Andreu, M.J., Bordas, M.A., Zorrilla, I., Moriñigo, M.A., Borrego, J.J., 1998. Pathogenicity of Vibrio alginolyticus for cultured gilt-head sea bream (Sparus aurata L.) Applied and environmental Microbiology 64, 4269-4275.

Bell, T.A., Ligtner, D.V., 1987. An outline of penaeid shrimp culture methods including infectious disease problems and priority drug treatments. Vet. Humam Toxicol. 29(1), 3743.

Boyd, C.E., Tucker, C.S., 1995. Sustainability of channel catfish farming. World Aquaculture 26(3), 45-53.

Boyd, C.E., 1995. Bottom soils, sediment and pond aquaculture. Chapman and Hall editions, New York, USA, 348 p.

Caldéron, J., Bayot, B., Sonnenholzner, S., Cornejo, M.H., Melana, J., Panchana, F., 2000. El mundo Acuícola 6, 13-17, Fundacion CENAIM-ESPOL, Guayaquil, Ecuador.

Costa, R., Mermoud, I., Koblavi, S., Morlet, B., Haffner, P., Berthe, F., Legroumellec, M., Grimont, P., 1998. Isolation and characterization of bacteria associated with Penaeus stylirostris disease (Syndrome 93) in New Caledonia. Aquaculture 164, 297-309.

Fegan, D.F., Clifford III, H.C., 2001. Health management for viral diseases in shrimp farms. In: Browdy C.L. and Jory D.E., editors. 2001. The New Wave, Proceedings of the Special Session on Sustainable Shrimp Culture, Aquaculture 2001. The World Aquaculture Society, Baton Rouge, Baton Rouge, Louisiana, United States, pp168-192.

Goarant, C., Merien, F., Berthe, F., Mermoud, I., Perolat, P., 1999. Arbitrarily primed PCR to type Vibrio spp. pathogenic for shrimp. Applied and environmental Microbiology 65, 1145-1151.

Goarant, C., Herlin, J., Imbert, F., Domalain, D., Marteau, A.L., 2004. Epidémiologie de Vibrio nigripulchritudo dans le cadre du syndrome d'été: résultats préliminaires du programme Désans. In : Styli 2003. Trente ans de crevetticulture en Nouvelle Calédonie. Nouméa-Koné, 2-6 juin 2003. Ed. IFREMER, Actes Colloq., 38, 210-215.

Goarant, C., Ansquer, D., Herlin, J., Domalain, D., Imbert, F., and De Decker, S., 2006. "Summer syndrome" in Litopenaeus stylirostris in New Caledonia: Pathology and epidemiology of the etiological agent, Vibrio nigripulchritudo. Aquaculture 253, 105-113.

Goarant, C., Reynaud, Y., Ansquer, D., de Decker, S., Saulnier, D., Le Roux, F., in press. Molecular epidemiology of Vibrio nigripulchritudo, a pathogen of cultured penaeid shrimp (Litopenaeus stylirostris) in New Caledonia. Systematic and Applied Microbiology, in Press. Available online 18 January 2006.

Harache, Y., Herbland, A., 2004. Le programme Désans (Défi Santé Stylirostris) : une démarche comparable au défi Morest appliqué à la filière crevette calédonienne. In : Styli 
2003. Trente ans de crevetticulture en Nouvelle Calédonie. Nouméa-Koné, 2-6 juin 2003. Ed. IFREMER, Actes Colloq., 38, 31-39.

Herlin, 1999. Prawn farming in New Caledonia. In: Rosenberry, B. (Ed.), World shrimp farming 1999. Shrimp news international vol. 13.

Holm-Hansen, O., Lorenzen, C.J., Holmes, P.E., Strickland, J.D.H., 1965. Fluorometric determination of chlorophyll. Journal du conseil international pour l'exploitation de la mer 30, 3-15.

Horowitz, A. and Horowitz, S., 2001. Disease control in shrimp aquaculture from a microbial ecology persepective. In: Browdy C.L. and Jory D.E., editors. 2001. The New Wave, Proceedings of the Special Session on Sustainable Shrimp Culture, Aquaculture 2001. The World Aquaculture Society, Baton Rouge, Baton Rouge, Louisiana, United States, pp. 199-218.

Kautsky, N., Rönnbäck, P., Tedengren, M., Troell M., 2000. Ecosystem perspectives on management of disease in shrimp pond farming. Aquaculture 191, 145-161.

La Rosa, T., Mirto, S., Mazzola, A., Danovaro, R., 2001. Differential responses of benthic microbes and meiofauna to fish-farm disturbance in coastal sediments. Environmental Pollution 112, 427-434.

Lavilla-Pitogo, C.R., Leano, E.M., Paner, M.G., 1998. Mortalities of pond-cultured juvenile shrimp, Penaeus monodon, associated with dominance of luminescent Vibrios in the rearing environment. Aquaculture 164, 337-349.

Le Moullac, G., Le Groumellec, M., Ansquer, D., Froissard, S., Levy, P., 1997. Haematological and phenoloxidase activity changes in the shrimp Penaeus stylirostris in relation with molt cycle: protection against vibriosis. Fish and Shellfish Immunology 7, 227-234.

Le Moullac, G., Soyez, C., Saulnier, D., Ansquer, D., Avarre, J.C., Levy, P., 1998. Effect of hypoxic stress on the immune response and the resistance to vibriosis of the shrimp Penaeus stylirostris. Fish and Shellfish Immunology 8, 621-629.

Lefevre, J., Lemonnier, H., Goarant, C., Blanchot, J., 2004. Evolution des paramètres physico-chimiques et biologiques de bassins d'élevage de crevettes soumis à deux régimes de renouvellement en eau avant et pendant des mortalités de type «syndrome 93 ». In: Styli 2003. Trente ans de crevetticulture en Nouvelle Calédonie. Nouméa-Koné, 2-6 juin 2003. Ed. IFREMER, Actes Colloq., 38, 158-166.

Lemonnier, H., Martin, J.L.M., Brizard, R., Herlin, J., 2003. Effect of water exchange rate on waste production in semi intensive shrimp ponds during the cold season in New Caledonia. Journal of the World Aquaculture Society 34(1), 40-49.

Lemonnier, H., personnel du LAC, 2004. Environnement bassin et vibriose dans des élevages de crevettes de saison chaude en Nouvelle Calédonie: résultats préliminaires du progamme Désans. In : Styli 2003. Trente ans de crevetticulture en Nouvelle Calédonie. Nouméa-Koné, 2-6 juin 2003. Ed. IFREMER, Actes Colloq., 38, 180-186.

Lemonnier, H., Faninoz, S., 2006. Effect of water exchange on effluent and sediment characteristics and on partial nitrogen budget in semi-intensive shrimp ponds in New Caledonia. Aquaculture Research 37: 938-948.

Lightner, 1993. Diseases of cultured shrimp. In: Mc Vey, J.P. (Ed), Handbook of mariculture: Crustacean Aquaculture, $2^{\text {nd }}$ ed., CRC Press, Boca Raton, FL 1, pp. 393-486.

Lightner, D.V., Redman, R.M., 1998. Shrimp diseases and current diagnosis methods. Aquaculture 164, 201-220.

Lotz, J. M., Davidson, J., Soto, M.A., 2001. Two approaches to epidemiology in shrimp aquaculture disease control. In: Browdy C.L. and Jory D.E., editors. 2001. The New Wave, Proceedings of the Special Session on Sustainable Shrimp Culture, Aquaculture 
2001. The World Aquaculture Society, Baton Rouge, Baton Rouge, Louisiana, United States, pp219-225.

Martin, J.L.M., Veran, Y., Guelorget, O., Pham, D., 1998. Shrimp rearing: stocking density, growth, impact on sediment, waste output; their relationships studied through the nitrogen budget in rearing ponds. Aquaculture 164, 135-149.

Mermoud, I., Costa, R., Ferré, O., Goarant, C., Haffner, P., 1998. 'Syndrome 93' in New Caledonia outdoor rearing ponds of Penaeus stylirostris: history and description of three major outbreaks. Aquaculture 164, 323-335.

Mugnier, C., Justou, C., personnel du LAC, 2004. La crevette et le Syndrome d'été en Nouvelle Calédonie : quelles réponses physiologiques et immunitaires ? Résultats préliminaires du programme Désans. In : Styli 2003. Trente ans de crevetticulture en Nouvelle Calédonie. Nouméa-Koné, 2-6 juin 2003. Ed. IFREMER, Actes Colloq., 85-92.

Nash, G.L., 1990. Penaeus monodon grow-out diseases. In: Proceeding of the Aquatech'90 Conference Kuala Lumpur, New, Michael B. New, Henri de Saram and Tarlochan Singf Editors, Malaysia, 11-14 June 1990, pp. 172-182.

National Oceanic and Atmospheric Administration, U.S. department of Commerce, 2005. http://www.cdc.noaa.gov/people/klaus.wolter/MEI/mei.html\#LaNina.

Nicet, J.B., Delcroix, T., 2000. ENSO-Related Precipitation Changes in New Caledonia, Southwestern Tropical Pacific: 1969-98. Monthly Weather Review: Vol. 128(8), pp. 3001-3006.

Shivappa, R.B., 1997. Efficacy of probiotics and disinfectants in controlling luminescent bacteria in shrimp post larvae under normal and stressed conditions. MSc Thesis, Asian Institute of Technology, Bangkok.

Snieszko, S.F., 1974.The effect of environmental stress on outbreaks of infectious diseases of fish. Journal of Fisheries Biology 6, 197-208.

Spaargaren, D.R., 1998. Cultivation of tiger prawns, Penaeus monodon, Fabricius, 1798 (Decapoda, Natantia) in Hainan, PR China. Crustaceana 71(2), 144-157. 
Table 1: Number of crops studied $(\mathrm{N})$, mean final survival, final density, number of dead shrimp counted between d25 to d120 on pond edges and on feeding trays, mortality outbreak characteristics on the diseased farm DF.

\begin{tabular}{|c|c|c|c|c|c|c|}
\hline Years & $\mathrm{N}$ & $\begin{array}{c}\text { Final } \\
\text { Survival (\%) }\end{array}$ & $\begin{array}{l}\text { Final density } \\
\text { (Shrimp/m2) }\end{array}$ & $\begin{array}{c}\text { Number of } \\
\text { dead shrimp } \\
\text { on pond edges }\end{array}$ & $\begin{array}{l}\text { Number of dead } \\
\text { shrimp on } \\
\text { feeding trays }\end{array}$ & Mortality characteristics \\
\hline 199 & 2 & 1 & $10.7 \pm 0.3$ & $697 \pm 57$ & $75 \pm 69$ & \\
\hline 1998 & 7 & $36.7 \pm 4.5$ & 10.0 & $325 \pm 364$ & 10 & Weak and \\
\hline 1999 & 5 & $25.4 \pm 5.0$ & $6.9 \pm 1.2$ & $435 \pm 303$ & $84 \pm 61$ & $\begin{array}{l}\text { Weak and chronic ( } 2 \text { crops) } \\
\text { Successive peaks ( } 3 \text { crops) }\end{array}$ \\
\hline $\begin{array}{l}2000 \\
2001\end{array}$ & $\begin{array}{l}7 \\
5\end{array}$ & $\begin{array}{l}22.3 \pm 2.6 \\
30.9 \pm 6.9\end{array}$ & $\begin{array}{l}7.5 \pm 0.7 \\
9.8 \pm 1.3\end{array}$ & $\begin{array}{l}1055 \pm 719 \\
1800 \pm 2658\end{array}$ & $\begin{array}{l}256 \pm 128 \\
364 \pm 264\end{array}$ & $\begin{array}{l}5 \text { or } 6 \text { successive peaks } \\
2 \text { high successive peaks }\end{array}$ \\
\hline
\end{tabular}

Table 2: Temperature, oxygen, salinity at which first dead shrimp were observed in diseased farm DF for crops affected by the "Summer Syndrome" ( $\mathrm{N}=26)$.

\begin{tabular}{ccccccc}
\hline Years & Code & $\begin{array}{c}\mathrm{T} \text { am } \\
\left({ }^{\circ} \mathrm{C}\right)\end{array}$ & $\begin{array}{c}\mathrm{T} \text { pm } \\
\left({ }^{\circ} \mathrm{C}\right)\end{array}$ & $\begin{array}{c}\text { Oxygen am } \\
(\mathrm{mg} / \mathrm{L})\end{array}$ & $\begin{array}{c}\text { Oxygen pm } \\
(\mathrm{mg} / \mathrm{L})\end{array}$ & $\begin{array}{c}\text { Salinity } \\
(\%)\end{array}$ \\
\hline 1997 & 92 & 29.0 & 31.0 & 4.0 & 8.3 & 40 \\
1997 & 93 & 28.0 & 31.0 & 2.2 & 7.0 & 40 \\
1998 & 101 & 24.4 & $\underline{24.0}$ & nd & nd & 40 \\
1998 & 102 & $\underline{24.0}$ & 26.0 & nd & nd & 36 \\
1998 & 103 & $\underline{24.0}$ & $\underline{24.0}$ & nd & nd & $\underline{36}$ \\
1998 & 104 & 27.5 & 31.0 & nd & nd & 39 \\
1998 & 105 & 26.0 & 28.0 & nd & nd & 38 \\
1998 & 106 & 28.0 & 31.0 & nd & nd & 38 \\
1998 & 107 & 27.5 & 30.0 & nd & nd & 37 \\
1999 & 116 & 26.1 & 29.2 & nd & nd & nd \\
1999 & 117 & 28.0 & 31.5 & 4.0 & nd & nd \\
1999 & 118 & 27.1 & 32.1 & 4.5 & nd & nd \\
1999 & 119 & 28.3 & 29.5 & 4.0 & nd & nd \\
1999 & 120 & 28.0 & 31.5 & 4.0 & nd & nd \\
2000 & 129 & 24.5 & 27.7 & 3.2 & 9.2 & $\mathbf{4 1}$ \\
2000 & 130 & 25.3 & 27.8 & 4.5 & $\mathbf{1 0 . 7}$ & 37 \\
2000 & 131 & 26.5 & 28.1 & $\underline{1.1}$ & $\underline{3.3}$ & 39 \\
2000 & 132 & 28.7 & 29.2 & 4.0 & 8.7 & 37 \\
2000 & 133 & 24.8 & 26.4 & 4.0 & 9.7 & 37 \\
2000 & 134 & 26.0 & 28.0 & 4.0 & 5.3 & 38 \\
2000 & 135 & 28.2 & 30.1 & 2.5 & 8.5 & 38 \\
2001 & 136 & 29.3 & 30.3 & 3.5 & 8.5 & 37 \\
2001 & 137 & 24.4 & 27.2 & 4.2 & 7.3 & 37 \\
2001 & 138 & 28.2 & 31.4 & 4.2 & 7.8 & 37 \\
2001 & 140 & $\mathbf{2 9 . 9}$ & $\mathbf{3 2 . 5}$ & 4.0 & 8.3 & 39 \\
2001 & 142 & 26.0 & 28.6 & $\mathbf{4 . 7}$ & 9.0 & 38 \\
& & & & & & 38 \\
\hline Mean & & 26.8 & 29.3 & 3.7 & 8.0 & 1 \\
S.D. & & 1.8 & 2.1 & 0.9 & 1.9 & \\
\hline
\end{tabular}

Bold data is the maxima; Underlined data is the minima. nd: not determinated 


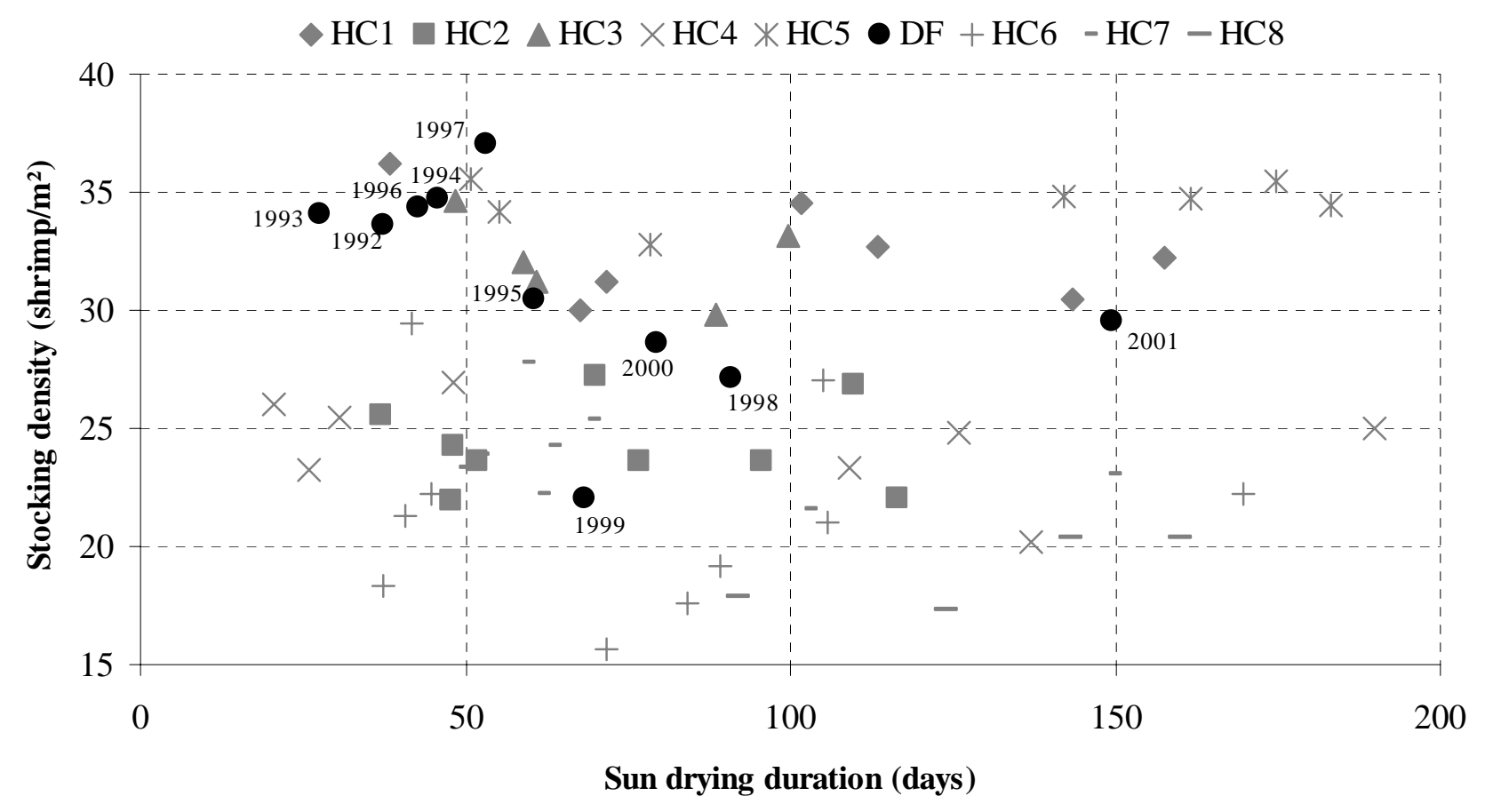

Fig. 1. Annual average stocking density $\left(\operatorname{shrimp} / \mathrm{m}^{2}\right)$ in relation with annual average sun drying duration (days) in different farms in New Caledonia. Circles in black represent DF.

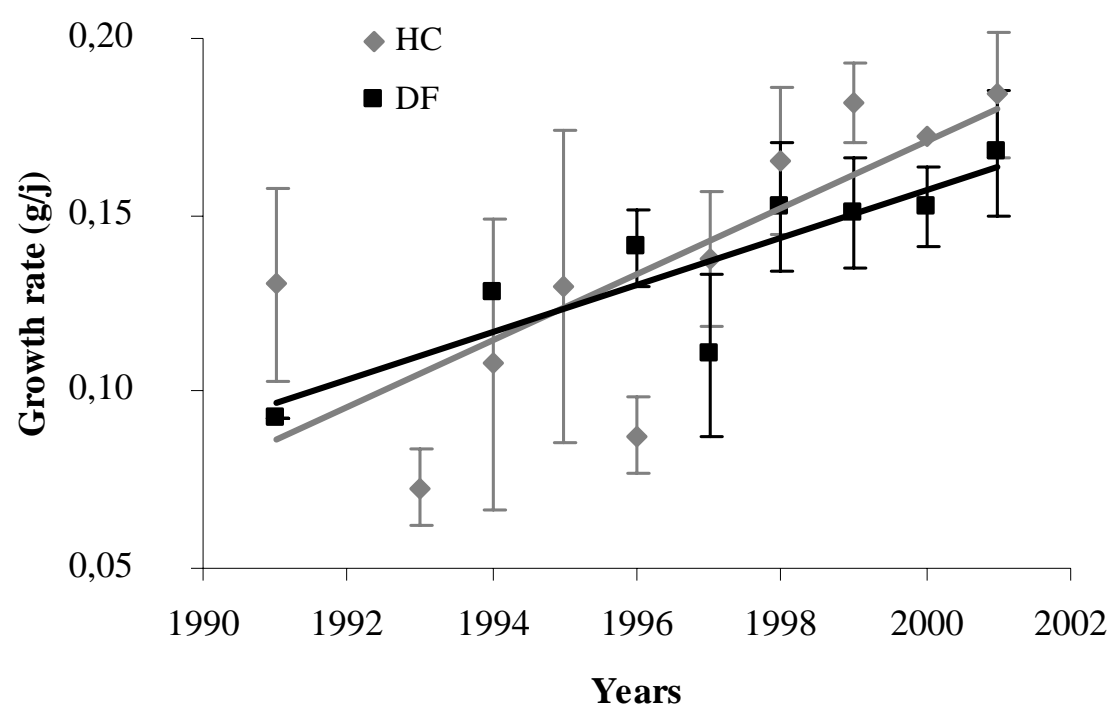

Fig. 2. Mean growth rate in relation to time in control farms (HC) and diseased farm (DF) 50 days after stocking. 

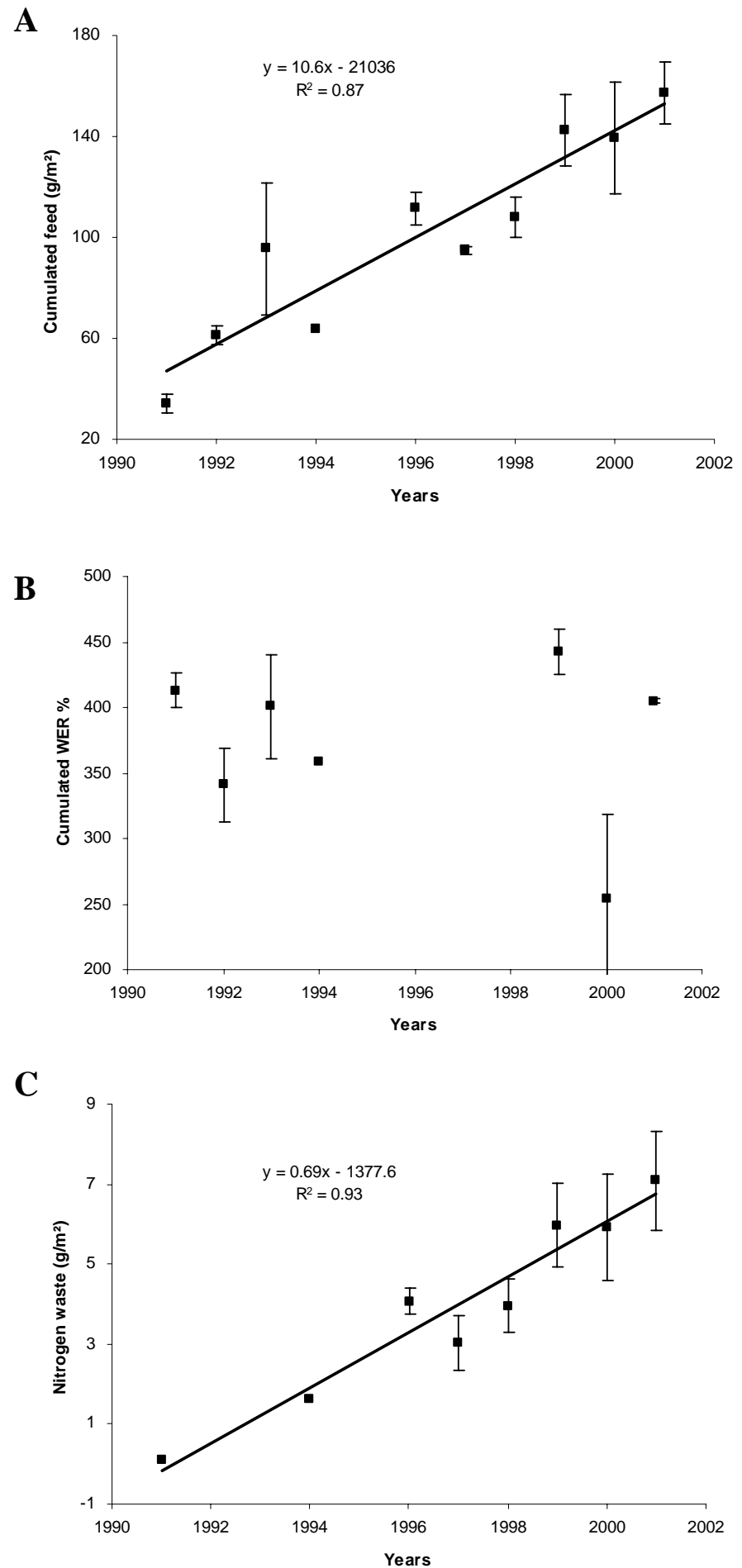

Fig. 3. The sum total of feed $(\mathrm{N}=35)(\mathrm{A})$, water exchange $(\mathrm{N}=24)(\mathrm{B})$ and nitrogen waste input in the first 50 days after stocking plotted against time in the disease farm (farm DF). 

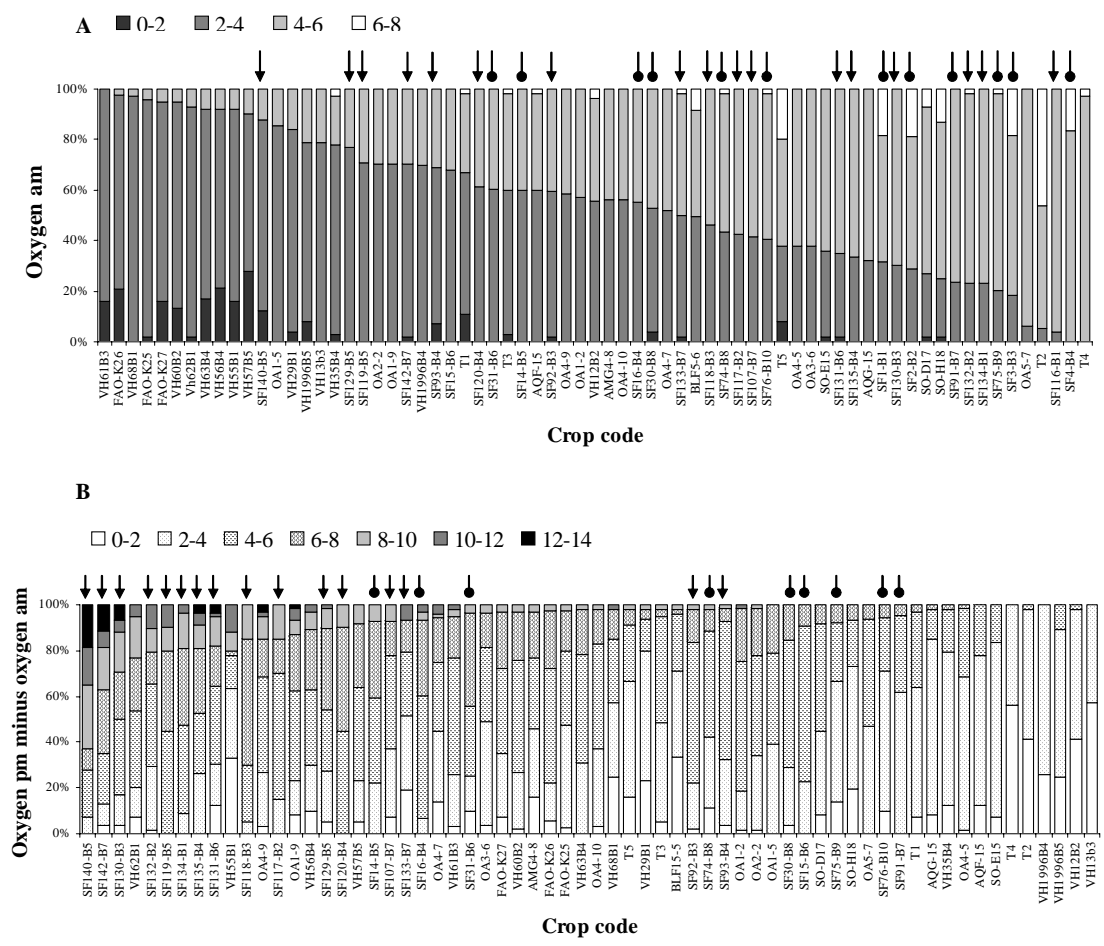

Fig. 4. Oxygen morning (A) $(\mathrm{N}=69)$ and net oxygen budget $(\mathrm{B})(\mathrm{N}=62)$ distribution (\%) measured between d60 and d120 for ponds stocked between September to November. Values are expressed as class frequency. Crop were classified with frequency $<4 \mathrm{mg} / \mathrm{L}$ (A) and $>8$ $\mathrm{mg} / \mathrm{L}(\mathrm{B})^{\circ} \mathrm{DF}$ with Summer syndrome $\downarrow$; without Summer syndrome • 


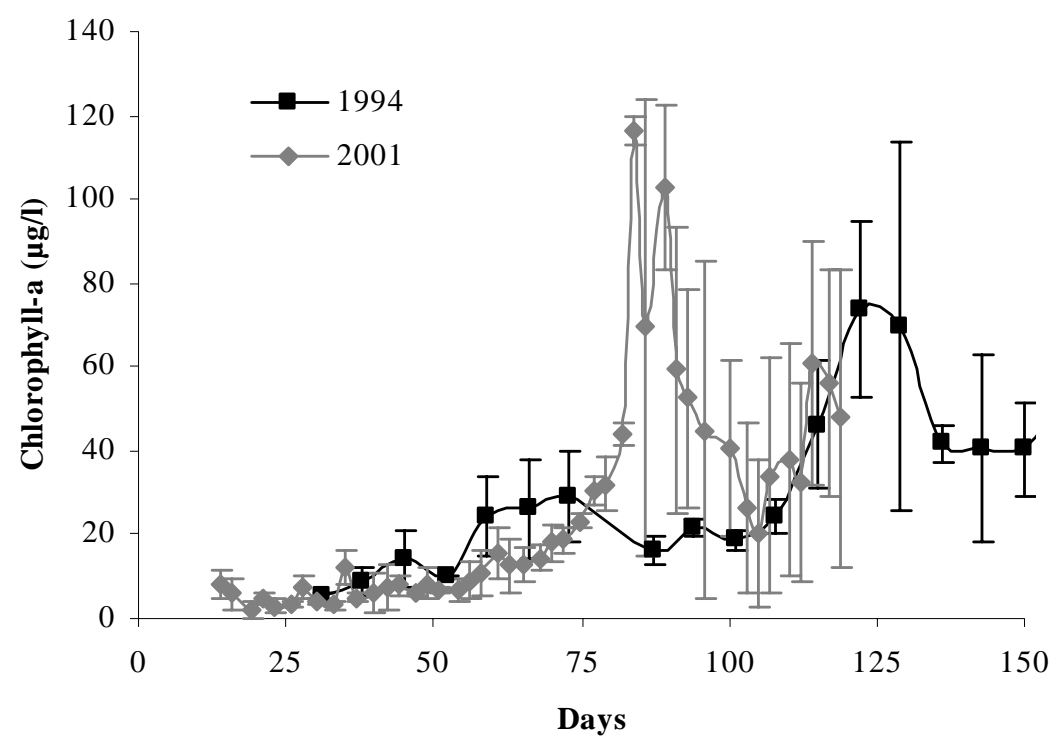

Fig. 5. Daily average chlorophyll-a concentrations in ponds stocked in august $1994(\mathrm{~N}=2)$ and august $2001(\mathrm{~N}=3)$ in disease farm (DF). 